\title{
Clinical and Pathological Studies on the Etiological Factors of Bovine Abomasal Displacement and Atony
}

\author{
I. Clinical Cases
}

\author{
Haruo YAMADA \\ Department of Veterinary Surgery, School of Veterinary Medicine, Obihiro University \\ of Agriculture and Veterinary Medicine, Inada-cho, Obihiro-shi, Hokkaido 080
}

(Received for publication December 1, 1980)

\begin{abstract}
In order to clarify an etiological factor of bovine abomasal displacement and atony, 24 clinical cases of bovine abomasal displacement were studied mainly fluoroscopically and histopathologically. Of them, fourteen were operated successfully to recover and ten slaughtered to investigate pathological changes. In addition to the dilatation and displacement of the abomasum, some significant findings were obtained by fluoroscopy. They were signs of severe forestomach disorders in the form of ruminal dilatation, bloat, impaction, reticular atony, and slow and weak contraction of the reticulum. The presence of sharp metallic foreign bodies in the reticulum was significantly observed in $92 \%$ of the cases. The histopathologic findings were characterized by relatively fresh degenerative lesions in the smooth muscle and intramural nerve fibers of the omasum and abomasum with blood vessels altered (edematous loosening and swelling of the wall) and by rather old degenerative lesions of the same tissues in the reticulum. In 2 cases which had developed inflammatory reactions near the reticular plexus below the cardia, rather old lesions were found not only in the reticulum but also in the omasum and abomasum. From the results of this study it was suggested that forestomach disorders might exist as pre-cursors of abomasal displacement and atony, and that at least as one of the etiological factors of the forestomach disorders, the presence of sharp foreign bodies in the reticulum might have significant meaning.
\end{abstract}

Studies on the etiology of abomasal displacement and atony in cattle are relatively sparse. Several hypotheses have already been reported on the causative relations, but none of them seem to have been supported by sufficient experimental evidences.

Many investigators believe that abomasal displacement is associated with pregnancy and parturition because of the frequent occurrence of the disease during these periods $[1,2,16,19]$. It has also been known, however, that abomasal displacement occurs not only in pregnant or postpartum cows, but also in young cattle [20] and in the opposite sex [12, 20]. Dirksen [6] and other workers $[10,14,17,19]$ have established that abomasal atony and dilatation are essential pre-requisites for the occurrence of abomasal displacement. Abomasal atony usually appears to result from several enumerated factors $[6,14-16,19]$, which have not been surely established.

The purpose of the present study was, therefore, to elucidate the etiological factors of bovine abomasal displacement and atony in clinical cases mainly from a fluoroscopical and histopathological point of view.

\section{Materials and Methods}

Animals: Twenty-four Holstein-Friesian cows 
with abomasal displacement referred to the Veterinary Hospital of Obihiro University over a period July, 1976 to May, 1978 were investigated. Of them fourteen (Case Nos. 1-14) were operated and recovered. They were 3 to 6 years old and took a course of disease extending from some hours to 4 days (mostly within 1 day). The others (Case Nos. 15-24) were sent to the slaughterhouse either because of poor prognosis or upon request of the owner. They were 2 to 9 years old and took a course of disease extending from 1 to 15 days.

General examination: Clinical histories were obtained from the owners. Physical examinations were performed by auscultation, palpation, percussion, inspection, ballottement, etc. Blood examinations were also done, but their results were not included in this report.

Fluoroscopic examination: Fluoroscopic findings were obtained by using an X-ray television system for large animals (Hitachi MR-300-3, Japan), and recorded by a video tape for future references. Animal patients were restrained in a stanchion, with the X-ray tube on the left side, and the fluorescent screen on the right. The focus-screen distance was $150 \mathrm{~cm}$. The irradiation factors were $250-300 \mathrm{kVp}$, 7-9 mA continuously for 5-15 minutes. The grid had a ratio of 10:1. The copper filter had a $2 \mathrm{~mm}$ half value.

Fluoroscopic criteria: The criteria used for the diagnosis of different bovine abdominal disorders in this study were similar to those mentioned in the previous report from the author's laboratory [24].

Postmortem examination: (a) Gross examination. All the slaughtered animals (Nos. 15-24) were examined for abnormalities of various organ. Anatomical measurements were made on the reticulum, amasum, and abomasum after the removal of their contents. The atony of these organs was graded by the anatomical measurement, mucosal decoloration, and general appearance of the organ. (b) Histopathological examination. After macroscopic observation, tissue specimens were collected from the liver, spleen, kidneys, heart, lungs, stomach, cervical and thoracic sympathetic nerve trunks, abdominal vagal trunk, and anterior cervical ganglion. In the complex stomach, many blocks of tissues were collected from various parts, such as the dorsal and ventral curvature of the rumen, atrium ruminis, diaphragmatic and visceral walls, fundus of the reticulum, reticular groove, omaso-abomasal orifice, fundic and pyloric gland areas of the abomasum, and pylorus. All of them were fixed in $10 \%$ neutral formalin to prepare paraffin sections, which stained with hematoxylin and eosin (H-E).

\section{Results}

Clinical history: Twenty-two of the 24 animals had histories of previous illnesses, the majority of which were digestive disorders. Nine animals had abomasal displacement, consisting of five with left-sided displacement of the abomasum (LDA) and four with right-sided displacement of the abomasum (RDA). Fifteen had ketosis, two ruminal impaction, two generalized forestomach atony, and one bloat.

Clinical findings: All the animals were found to be fair to very poor in conditions. Defecation was little or scant. Rumen motility was invariably reduced. Auscultation of an area occupied by the last 4 ribs on the left or right side with percussion of the last rib revealed an increase in resonance (positive ping test) $[4,18]$ in all the animals. In addition, high-pitched "tinkle", characteristic of abomasal displacement in cattle $[1,2,10,12,14]$, could also be heard in 15 animals. Ketonuria was seen in 14 animals.

Fluoroscopy: The fluoroscopic findings of the 24 animals are summarized in Tables 1 and 2. There were sixteen cases of LDA (Fig. 1) and eight cases (Nos. 5, 15, 16, 18, and 21-24) of RDA (Fig. 2). Reticular atony (Fig. 3) with slow and weak contraction was seen in all the 24 cases. A monophasic reticular contraction without the second phase was observed in 11 cases. Rumen impaction (Fig. 4) was visualized in another 11 cases, and bloat in another 11 cases. Sharp metallic foreign bodies were contained in the reticulum (Fig. 5) in 22 cases of which eight had wire implanted in the reticular wall. In 2 cases (Nos. 7 and 15), the second phase of reticular biphasic contraction was prevented by wire picks. When the wire tips touched the reticular wall during the first phase, the second phase was omitted, and the A sequence of ruminal 
Table 1. X-ray fluoroscopic findings in the forestomach and abomasum of recovered cases

\begin{tabular}{|c|c|c|c|c|c|c|c|c|c|c|c|c|c|}
\hline \multirow[b]{3}{*}{$\begin{array}{l}\dot{0} \\
\dot{z} \\
\ddot{g}\end{array}$} & \multicolumn{4}{|c|}{ Rumen } & \multicolumn{4}{|c|}{ Reticulum } & \multicolumn{5}{|c|}{ Abomasum } \\
\hline & \multicolumn{3}{|c|}{ Ingesta } & \multirow[b]{2}{*}{ 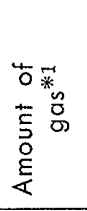 } & \multicolumn{2}{|c|}{ Contraction*2 } & \multirow[b]{2}{*}{ 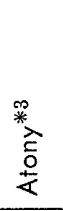 } & \multirow{2}{*}{ 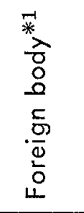 } & \multirow[b]{2}{*}{ 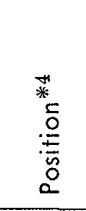 } & \multirow[b]{2}{*}{ 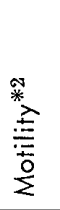 } & \multirow[b]{2}{*}{ 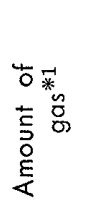 } & \multicolumn{2}{|c|}{ Ingesta } \\
\hline & 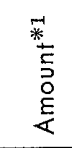 & $\begin{array}{l}\stackrel{\lambda}{\bar{\Xi}} \\
\stackrel{\partial}{0} \\
\vec{o}\end{array}$ & 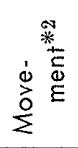 & & $\begin{array}{l}- \\
0 \\
\ddot{0} \\
\frac{0}{0}\end{array}$ & $\begin{array}{c}= \\
\Phi \\
\ddot{0} \\
\frac{5}{\alpha}\end{array}$ & & & & & & $\begin{array}{l}\vec{*} \\
\stackrel{+}{5} \\
\stackrel{0}{5} \\
\stackrel{5}{4}\end{array}$ & 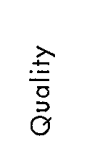 \\
\hline 1 & H & Soft & + & H & + & + & H & H & LDA & $N$ & H & + & Liquid \\
\hline 2 & H & 11 & - & + & + & - & H & H & 11 & $N$ & $H$ & + & $\prime \prime$ \\
\hline 3 & H & 11 & + & H & + & + & $H$ & + & "I & + & + & + & $\prime \prime$ \\
\hline 4 & + & $\prime \prime$ & + & H & + & + & $H$ & H & 11 & $N$ & H & + & $\prime \prime$ \\
\hline 5 & H & Hard & + & + & + & + & $H$ & H & $\mathrm{RDA}$ & $N$ & $H$ & $H$ & 11 \\
\hline 6 & + & Soft & + & m & + & + & $H$ & H & LDA & + & $H$ & $H$ & 11 \\
\hline 7 & $H$ & $\prime \prime$ & + & H & + & - & \# & + & $\prime \prime$ & $N$ & $H$ & $H$ & $" \prime$ \\
\hline 8 & $H$ & Hard & + & + & + & + & $H$ & H & "I & + & $H$ & $H$ & $\prime \prime$ \\
\hline 9 & 世 & $\prime \prime$ & - & + & $N$ & + & $H$ & $H$ & "I & + & H & $H$ & 11 \\
\hline 10 & H & "I & + & H & + & - & H & $H$ & "I & $N$ & 世 & H & 11 \\
\hline 11 & H & 11 & + & + & + & - & H & + & 11 & $N$ & $H$ & $H$ & 11 \\
\hline 12 & H & $\prime \prime$ & + & + & + & + & $H$ & $H$ & $\prime \prime$ & $N$ & $H$ & $H$ & 11 \\
\hline 13 & $\mathrm{Ht}$ & "I & + & + & + & + & W & + & 11 & $N$ & H & $H$ & $\prime \prime$ \\
\hline 14 & + & Soft & + & $H$ & $N$ & + & m & + & " & $N$ & $H$ & $H$ & "I \\
\hline : & $\begin{array}{l}\text { Sma } \\
\text { Larg } \\
\text { Extr }\end{array}$ & $\begin{array}{l}\text { I. } \\
\text { mely Io. }\end{array}$ & arge. & $\begin{array}{l}-, A \\
N, N \\
+, V\end{array}$ & $\begin{array}{l}\text { ent. } \\
\text { mal. } \\
\text { ak and }\end{array}$ & low. & 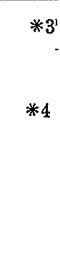 & $\begin{array}{l}\text { H, } \\
\text { HI, } \\
\text { LDA, } \\
\text { RDA, }\end{array}$ & $\begin{array}{l}\text { Modero } \\
\text { Severe. } \\
\text { Left-si } \\
\text { abom } \\
\text { Right- } \\
\text { abom }\end{array}$ & um. & $\begin{array}{l}\text { isplacen } \\
\text { displac }\end{array}$ & ent 0 & $\begin{array}{l}\text { the } \\
\text { f the }\end{array}$ \\
\hline
\end{tabular}

movement could not proceed. The A sequence is form of rumen contraction which characteristically precedes every biphasic contraction of the reticulum [23]. A large amount of geosediment was visualized on the abomasum and ruminal floor in all the cases. It was sometimes hard packed and frequently loose in the form of gravel and sand grain (Fig. 6). An excessive amount of gas was also found in the dilated and displaced abomasum.

Two cases (Nos. 2 and 12) were examined before the onset of abomasal displacement. They manifested such significant features as rumen impaction, reticular and abomasal atony, and the presence of sharp foreign bodies in the reticulum.

Macroscopical findings: The autopsy findings obtained are summarized in Table 3. A severe generalized atony of the complex stomach was found in all the cases, except one (No. 17). Similar gross lesions were observed in almost all the cases. In the rumen, they were mucosal decoloration and slight to moderate absence of papillae. The reticulum exhibited mucosal decoloration and had several holes in which sharp foreign bodies were embedded horizontally to the honeycomb papillae (Fig. 7) in all cases. Mucosal polypus, intramural abscess and fibrin formed in the serosa near the reticular plexus below the cardia (Fig. 8) were found in 2 cases (Nos. 15 and 20). Pieces of wire were attached to the reticular mucosa and half-buried in it. In 8 cases, ulceration was observed in the omasal groove (Fig. 9) and pillars and reticular groove. The abomasum were affected with varying degrees of submucosal edema and mucosal ulcers (Fig. 10), which were irregular in shape and size 
Table 2. X-ray fluoroscopic findings of the forestomach and abomasum in autopsy cases

\begin{tabular}{|c|c|c|c|c|c|c|c|c|c|c|c|c|c|}
\hline \multirow[b]{3}{*}{$\begin{array}{l}\dot{0} \\
\dot{0} \\
\dot{0}\end{array}$} & \multicolumn{4}{|c|}{ Rumen } & \multicolumn{4}{|c|}{ Reticulum } & \multicolumn{5}{|c|}{ Abomasum } \\
\hline & \multicolumn{3}{|c|}{ Ingesta } & \multirow[b]{2}{*}{ 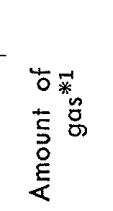 } & \multicolumn{2}{|c|}{ Contraction*2 } & \multirow[b]{2}{*}{ 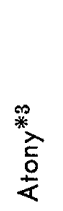 } & \multirow{2}{*}{ 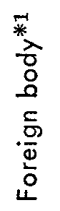 } & \multirow[b]{2}{*}{ 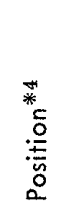 } & \multirow[b]{2}{*}{ 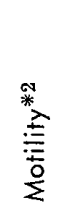 } & \multirow[b]{2}{*}{ 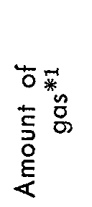 } & \multicolumn{2}{|c|}{ Ingesta } \\
\hline & 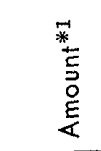 & 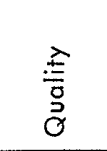 & 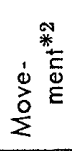 & & 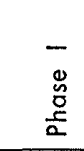 & $\begin{array}{l}= \\
\grave{o} \\
\ddot{c} \\
\frac{c}{a}\end{array}$ & & & & & & 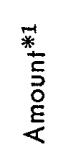 & $\begin{array}{l}\stackrel{\lambda}{\Xi} \\
\frac{0}{0} \\
0\end{array}$ \\
\hline 15 & H & Hard & + & + & + & - & $H$ & H & RDA & - & H & 册 & Liquid \\
\hline 16 & + & Soft & - & $H$ & + & - & $H$ & \# & $\prime \prime$ & + & H & $H$ & $\prime \prime$ \\
\hline 17 & 世 & Hard & - & + & + & - & $H$ & $H$ & LDA & + & H & 世 & " \\
\hline 18 & H & $\prime \prime$ & - & + & + & - & $H$ & + & RDA & - & 世 & \# & " \\
\hline 19 & $H$ & Soft & - & H & + & - & H & $H$ & LDA & + & \# & $H$ & $\prime \prime$ \\
\hline 20 & $H$ & $\prime \prime$ & - & + & + & - & $H$ & $H$ & $\prime \prime$ & - & 世 & \# & " \\
\hline 21 & + & Liquid & - & 世 & $t$ & + & H & $H$ & RDA & - & 世 & H & " \\
\hline 22 & $H$ & Hard & - & H & + & - & \# & + & $1 \prime$ & - & $H$ & $H$ & $\prime \prime$ \\
\hline 23 & + & Soft & - & W & + & - & \# & $H$ & $\prime \prime$ & + & H & H & " \\
\hline 24 & + & $\prime \prime$ & + & $\mathrm{HH}$ & + & + & \# & + & " & + & $H$ & H & 11 \\
\hline & $\begin{array}{l}\text { Sma } \\
\text { Larg } \\
\text { Extre }\end{array}$ & $\begin{array}{l}\text { all. } \\
\text { ye. } \\
\text { emely }\end{array}$ & *2: & $\begin{array}{l}\text { Abse } \\
\text { Wea }\end{array}$ & 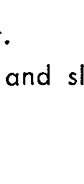 & $\begin{array}{l}* 3: \text { H } \\
\text { w. H }\end{array}$ & & & ${ }^{* 4}:$ & $\begin{array}{l}\text { LDA, } \\
\text { RDA, }\end{array}$ & $\begin{array}{l}\text { Left-sic } \\
\text { of the } \\
\text { Right-s } \\
\text { ment }\end{array}$ & $\begin{array}{l}d \text { dis } \\
\text { abom } \\
\text { ded d }\end{array}$ & $\begin{array}{l}\text { lacement } \\
\text { um. } \\
\text { place- } \\
\text { bomasum. }\end{array}$ \\
\hline
\end{tabular}

Table 3. Postmortem findings of the forestomach and abomasum in clinical cases

\begin{tabular}{|c|c|c|c|c|c|c|c|c|c|}
\hline \multirow[b]{2}{*}{$\begin{array}{l}\dot{0} \\
\dot{z} \\
\dot{0} \\
\dot{v}\end{array}$} & \multicolumn{2}{|c|}{ Rumen } & \multicolumn{3}{|c|}{ Reticulum } & \multicolumn{2}{|c|}{ Omrsum } & \multicolumn{2}{|c|}{ Abomasum } \\
\hline & 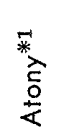 & 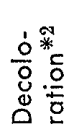 & 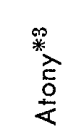 & 웅 & $\stackrel{*}{\stackrel{*}{\Delta}}$ & 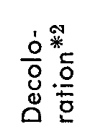 & 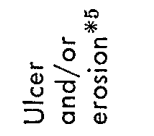 & 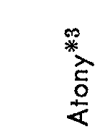 & 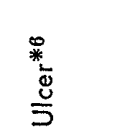 \\
\hline 15 & $H$ & $H$ & $H$ & $H$ & Diffuse & H & Scattered & 世 & 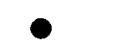 \\
\hline 16 & $H+$ & H & 世 & H & " & 世 & Diffuse & 世 & $\bullet$ \\
\hline 17 & $H$ & H & $H$ & H & Scaftered & $H$ & None & H & \\
\hline 18 & $H$ & \# & H & m & $\prime \prime$ & H & Scattered & H & \\
\hline 19 & $H$ & H & Ht & H & Diffuse & H & Diffuse & H & \\
\hline 20 & $H$ & H & Ht & \# & $\prime \prime$ & $H$ & Scattered & \# & 0 \\
\hline 21 & $H$ & m & HH & $H$ & "I & HI & "I & H & - \\
\hline 22 & $H$ & \# & $H$ & H & Scattered & \# & None & H & $\bullet$ \\
\hline 23 & \# & H & $H$ & H & $" 1$ & $H$ & Scattered & 世 & $\bullet$ \\
\hline 24 & H & 世 & H & H & $\prime \prime$ & H & "1 & H & $\bullet$ \\
\hline & $\begin{array}{l}\text { Milc } \\
\text { Moo } \\
\text { Seve }\end{array}$ & $\begin{array}{l}\text { inis. } \\
\text { te. }\end{array}$ & ${ }^{* 2}:$ H & $\begin{array}{l}\text { Modero } \\
\text { light br } \\
\text { Severe } \\
\text { whitish }\end{array}$ & $\begin{array}{l}\text { te (gray- } \\
\text { own). } \\
\text { (White- } \\
\text { yellow). }\end{array}$ & $\begin{array}{r}* 3:+ \\
\text { H } \\
\text { H. }\end{array}$ & $\begin{array}{l}\text { Mild. } \\
\text { Moderate. } \\
\text { Severe. }\end{array}$ & $\begin{array}{l}{ }^{* 4}: \operatorname{Ret} \\
* 5: O \mathrm{~m} \\
* 6: 1 \mathrm{~d}\end{array}$ & $\begin{array}{l}\text { folds. } \\
\text { groove. } \\
1 \text { ulcer. }\end{array}$ \\
\hline
\end{tabular}

( $4 \mathrm{~mm}-5 \mathrm{~cm}$ in diameter), either single or multiple, and seen mostly in the greater curvature of the fundic gland region.
Histopathological findings: These findings are summarized in Tables 4 and 5 .

1) Smooth muscle of the forestomach 
Table 4. Histopathological findings of smooth muscle of the forestomach and abomasum in bovine cases of abomasal displacement

\begin{tabular}{|c|c|c|c|c|c|c|c|c|c|c|c|c|c|c|c|c|}
\hline $\begin{array}{l}\dot{0} \\
\dot{Z} \\
\ddot{\Delta} \\
\dot{0}\end{array}$ & $\frac{9}{9}$ & 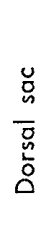 & 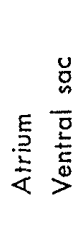 & \begin{tabular}{l}
$\frac{5}{5}$ \\
$\frac{5}{0}$ \\
\hdashline \\
$\alpha$
\end{tabular} & 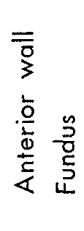 & 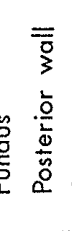 & $\begin{array}{l}0 \\
0 \\
0 \\
0\end{array}$ & 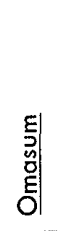 & 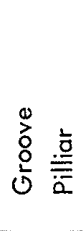 & 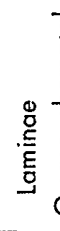 & 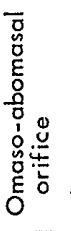 & 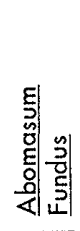 & 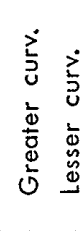 & 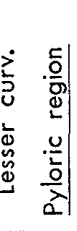 & 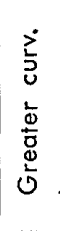 & 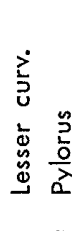 \\
\hline 15 & & $\mathbf{N}$ & (1) 0 & & $\odot \odot$ & $\odot \odot$ & () & & $\odot \odot$ & $\odot$ & $\odot$ & & (2) () & & () & $\odot \odot$ \\
\hline 16 & & $\mathbf{N}$ & $\mathbf{N} \mathbf{N}$ & & (1) (1) & 50 & (0) & & (2) 0 & 0 & - & & (1) (0) & (9) & () & (1) (0) \\
\hline 17 & & $\mathbf{N}$ & - $\mathrm{N}$ & & $\odot \odot$ & 0 & () & & (1) () & (0) & (1) & & (1) (1) & & () & () (ㅇ) \\
\hline 18 & & $\mathbf{N}$ & ON & & $\odot \odot$ & $\odot \odot$ & $\odot$ & & (1) () & (O) & - & & (1) (O) & & () & () $\odot$ \\
\hline 19 & & $\mathbf{N}$ & (1) 0 & & $\odot \odot$ & $\odot \odot$ & () & & $\odot \circ$ & (0) & - & & (1) (1) & & () & (1) () \\
\hline 20 & & 0 & (1) () & & $\odot \odot$ & $\odot \odot$ & $\bullet$ & & $\odot \odot$ & & $\odot$ & & $\odot \odot$ & & (.) & $\odot \odot$ \\
\hline 21 & & 0 & (a) 0 & & $\odot \odot$ & 0 & (a) & & $\odot \bullet$ & $\odot$ & (O) & & (1) (0) & & (c) & (2) (a) \\
\hline 22 & & $\mathbf{N}$ & ON & & $\odot \odot$ & 6 & () & & $($ ) $\odot$ & () & (2) & & (1) (1) & & (O) & (1) (0) \\
\hline 23 & & 0 & (a) 0 & & $\odot \odot$ & $\odot \odot$ & $\odot$ & & (ㅇ) & () & $\bullet$ & & $0 \odot$ & & () & (1) () \\
\hline 24 & & $\mathbf{N}$ & 00 & & $\odot \odot$ & 0 & 0 & & - (0) & & (1) & & & & 0 & (1) (O) \\
\hline
\end{tabular}

$\bigcirc$ : Relatively fresh localized lesions. $\quad$ : Rather old localized lesions.

(9): Relatively fresh diffuse lesions. $\odot$ : Rather old diffuse lesions.

- : Not examined. $\quad \mathbf{N}$ : No significant lesions were found.

Table 5. Histopathological findings in the intramural nerve fibers of the forestomach and abomasum, and selected nerve trunks and ganglion of the autonomic nervous system in bovine cases of abomasal displacement

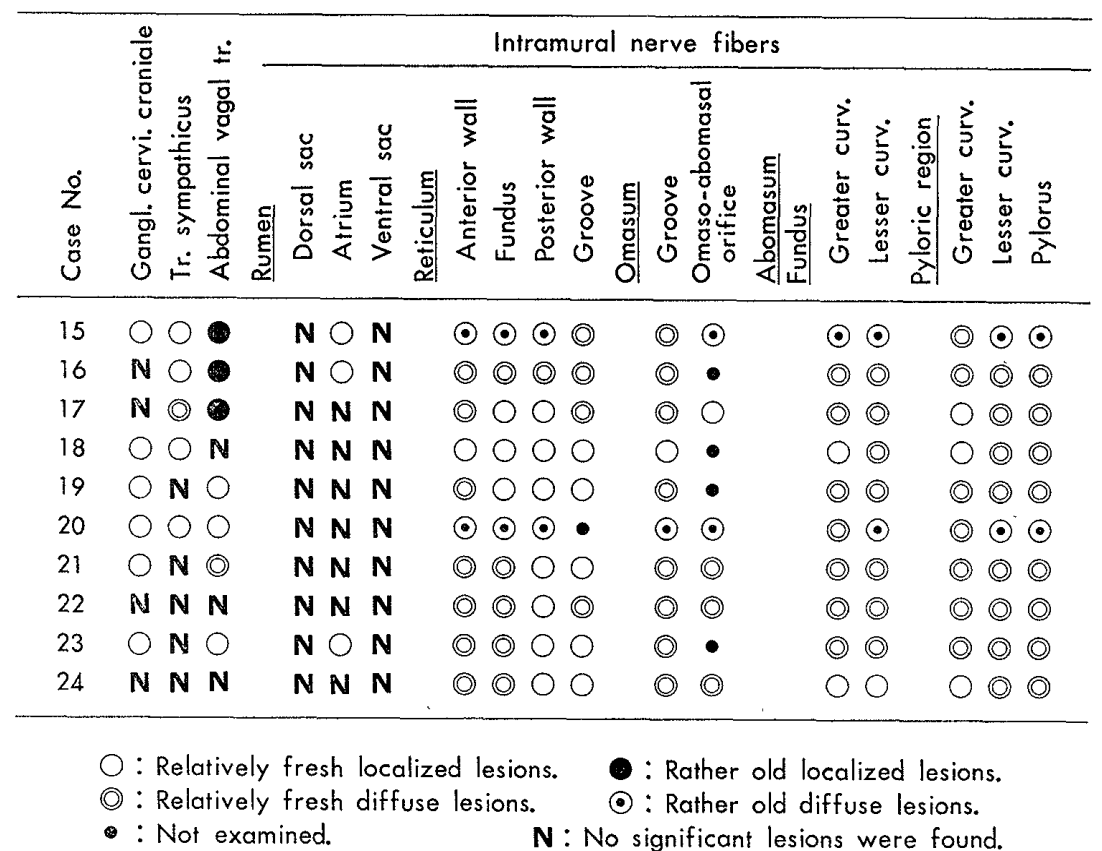

and abomasum. Two types of lesions were discriminated. The muscularor relatively fresh lesion consisted of edema and vacuolar or hydropic degeneration (Fig.s 11 and 12). The rather old lesion (Fig. 13) was charac- terized by loss of muscle fibers. It was accompanied with alteration of blood vessels (edematous loosening and swelling of the vascular wall). The relatively fresh lesion was generally found in the omasum, abo- 
masum, and sometimes rumen. The rather old lesion was observed mainly in the reticulum and sometimes in the omasal groove. In the two cases (Nos. 15 and 20) which developed inflammatory reactions near the reticular plexus below the cardia, the rather old lesion was found not only in the reticulum but also in the omasum and abomasum.

2) Intramural nerve fibers of the forestomach and abomasum. Changes in these nerve fibers were generally parallel in severity with lesions in the smooth muscle. The relatively fresh lesion with scavenger cells (Fig. 14) was seen in nerve fibers of the omasum and abomasum. The rather old lesion occasionally with concentric structures was found only in the reticulum. In those two cases, Nos. 15 and 20, rather old lesions were found not only in the reticulum but also in the omasum and abomasum (Fig. 15).

3) Other lesions in the complex stomach. The abomasal ulcer produced in all the cases were of chronic type (Fig. 16). They were characterized by leukocytic infiltration, proliferation of fibrous connective tissue, and vascularization. The ulcers produced in the omasal groove were mostly of chronic type.

4) Other organs. In the liver and kidneys, fatty degeneration was observed in two cases (Nos. 19 and 20).

\section{Discussion}

Although no directly etiological factors of abomasal displacement in cattle could be fully investigated in the present study, it is considered that abomasal atony and dilatation may be essential prerequisites for the occurrence of abomasal displacement, as asserted by Dirksen [6] and other workers $[10,14,17,19]$. From the present fluoroscopic and histopathological examination on 24 clinical cases of abomasal displacement, several pieces of information were obtained on the etiology of abomasal displacement and atony.

Firstly, it is suggested that forestomach disorders may be precursors for abomasal displacement and atony. This suggestion is supported by the following results: (1) Of the 24 animals, twenty had histories of previous illnesses which were ascribed to forestomach disorders. Fifteen had ketosis [21], two ruminal impaction, two generalized forestomach atony, and one bloat, (2) Fluoroscopy in all the cases indicated that severer signs were shown by forestomach disorders than by abomasal displacement and dilatation. These signs were very simialr to those reported previously in bovine forestomach diseases (chronic bloat, ruminal impaction, traumatic reticulitis, etc.) [24]. (3) When two animals (Nos. 2 and 12) were examined before the onset of abomasal displacement, they manifested some initial significant signs and abomasal atony, which are essential prerequisites for the occurrence of abomasal displacement $[6,10,14,17,19]$.

Secondly, it is pointed out that stagnation of the forestomach ingesta which is ascribed to forestomach disorders is one of the etiological factors of abomasal atony. Stevens et al. [22] stated that distention within a physiological range of the reticulorumen appeared to inhibit the contraction of the omasal canal and body and that, as a result, a large amount of ingesta in the reticulum and rumen flowed into the abomasum. On the other hand, it is well known that when a constant tension is applied to the smooth muscle for a relatively long time, the tension of the muscle fibers is extremely reduced (plasticity of the smooth muscle) [8]. In the clinical cases of this study, stagnation in the reticulorumen was observed by fluoro- 
scopy. This sign suggests that the stagnation of ingesta may give a distending stimulus to the wall of the forestomach.

In eight of the 10 autopsied cases, ulcers (chronic type) of the omasal groove were observed in gross and histological examinations. They may probably have occurred due to the back-flow of very acidic abomasal ingesta, which may have resulted in the inhibition of the reticulorumen with ingesta. In addition, these abnormalities in the forestomach indicate that as one of the factors of accumulation of ingesta in the abomasum, inhibition of the omasal canal contraction may have been enhanced causing coarse ruminal ingesta to flow into the abomasum. Finally, the ingesta accumulated in the abomasum may have induced abomasal atony and dilatation, because of loss of the tension of the smooth muscle.

Thirdly, it is presumed that the presence of sharp metallic foreign bodies in the reticulum may have been one of the important factors for the occurrence of forestomach disorders. The ruminal and reticular motility may play an important role in rumination and eructation, and be indispensable for fermentation, saturation, transference and digestion of ingesta [7]. The cycle of these events starts with the reticulum contracting in two stages [5]. Many workers $[3,7,13,21]$ are of the opinion that as long as these foreign bodies stick to the honeycomb mucosa of the reticulum without causing perforation, abscess, adhesion or any inflammatory change, they may be harmless.

In the present study, sharp metallic foreign bodies in the reticulum, including eight which were pieces of wire implanted in the reticular wall, were seen in 22 cases by fluoroscopy. In addition, several holes were bored by sharp foreign bodies in the honeycomb papillae of the reticulum in all the autopsied cases, and intramural abcess and fibrous formation were noticed grossly in the serosa near the reticular plexus below the cardia in two cases (Nos. 15 and 20). In two cases (Nos. 7 and 15) observed by fluoroscopy, the A sequence of ruminal movement ceased when the tip of a sharp foreign body touched the mucosa of the reticulum. This event made a denial of the previous opinion and suggested that the presence of sharp foreign bodies in the reticulum may lead to the occurrence of a generalized forestomach disorder.

Histopathological findings of the smooth muscle and intramural nerve fibers of the forestomach and abomasum suggested that a forestomach disorder might existe as one of the etiological factors of abomasal displacement. The ventral vagus nerve trunk (VVNT) contributes to the formation of a plexus of nerve fibers in the cranial aspect of the reticulum just below the cardia [5, 9]. It runs caudoventrally after leaving the reticular plexus for the omasum and abomasum. Kimata et al. [11] observed that electrical stimulation of the VVNT in goats could elicit contraction of the forestomach and abomasum, and that the contraction was severe in the abomasum, mild in the reticulum, slight in the omasum, and absent in the rumen. In 2 cases of the present study (Nos. 15 and 20), inflammatory reactions (intramural abscess, fibrous formation in the serosa, and half-buried wire in the mucosa) developed near the reticular plexus, and rather old degenerative lesions were found in the reticulum, omasum, and abomasum. Therefore, it was also inferred that "vagus indigestion", as advocated by Neal and Edwards [15], might be one of the etiological factors of abomasal displacement.

The results of this study suggested that forestomach disorders might act as precursors of abomasal displacement and atony. These disorders may be among the etiolo- 
gical factors of forestomach disorders and sharp foreign bodies in the reticulum may have significant meaning.

Acknowledgments. The author wishes to thank Professor T. Hirose, of the Department of Veterinary Surgery, Obihiro University of Agriculture and Veterinary Medicine, and Professor Y. Fujimoto, of the Department of Comparative Pathology, Faculty of Veterinary Medicine, Hokkaido University, for their valuable advice, encouragement and criticism during the preparation of this paper.

\section{References}

[1] Albert, T. F., and Ramey, D. B. (1964). Rightsided abomasal displacement in cattle. J. Am. Vet. Med. Assoc. 145, 553-557.

[2] Begg, H., and Whiteford, W. A. (1956). Dis. placement of the abomasum in the cow. Vet. Rec. 68, 122-125.

[3] Blood, D. C., and Henderson, J. A. (1960). Veterinary Medicine, Williams and Wilkins Co., Baltimore, U.S.A., 103-138.

[4] Boucher, W. B., and Abt, D. (1968). Rightsided dilatation of the bovine abomasum with torsion. J. Am. Vet. Med. Assoc. 153, 76-80.

[5] Comline, R. S., Silver, I. A., and Steven, D. H. (1968). Physiological anatomy of the ruminant stomach. In Handbook of Physiology. Code, C. F., editor, American Physiological Society, Washington, D.C., 2647-2671.

[6] Dirksen, G. (1961). Vorkommen, Ursachen und Entwicklung der linksseitigen Labmagenverlargerung (Dislocatio abomasi sinistra) des Rindes. Disch. Tieraerztl. Wochenschr. 68, $8-12$.

[7] Gibbons, W. J. (1970). The digestive system. In Bovine Medicine and Surgery and Herd Health Management. Gibbons, W. J., editor, American Veterinary Publications Inc., Santa Barbara, Cal., 409-458.

[8] Guyton, A. C. (1966). Contraction of muscle. In Textbook of Medical Physiology. Guyton, A. C., editor, 3rd ed., W.B. Saunders Co., Philadelphia and London, 89-106.

[9] Habel, R. E. (1956). A study of the innervation of the ruminant stomach. Cornell Vet. 46, 555-628.

[10] Jones, R. S. (1962). The position of the bovine abomasum: An abattoir survey. Vet. Rec. 74, 159-163.

[11] Kimata, H., Kuwabara, S., and Hosoya, S. (1962). Effects of disturbances in the autonomic nerves and gastric microflora in ruminants. I. Disturbances in the autonomic nerves J. Jpn. Vet. Med. Assoc. 15, 43-47 (in Japanese).

[12] Macleod, N. S. M. (1960). Displacement of the abomasum in bullock. Vet. Rec. 72, 416.

[13] Maddy, K. T. (1954). Incidence of perforation of the bovine reticulum. J. Am. Vet. Med. Assoc. 124, 113-115.

[14] Mason, T. A. (1967). Displacement of the bovine abomasum with gross dilatation and intestinal stasis. Vet. Rec. 80, 253-254.

[15] Neal, P. A., and Edwards, G. B. (1968). "Vagus indigestion" in cattle. Vet. Rec. 82, 396-402.

[16] Nilson, L. S. (1962). Etiology of abomasal displacement. Mod. Vet. Pract. 43, 68-70.

[17] Pinsent, P. J. N., Neal, P. A., and Ritchie, H. E. (1961). Displacement of the bovine abomasum: A review of 80 clinical cases. Vet. Rec. 73, 729-735.

[18] Robertson, J. M. (1965). Diagnossi of left displacement of the bovine abomasum. J. Am. Vet. Med. Assoc. 146, 820-827.

[19] Robertson, J. M. (1968). Left displacement of the bovine abomasum: Epizootiologic factors. Am. J. Vet. Res. 29, 421-434.

[20] Rosenberger, V. G., and Dirksen, G. (1957). Ueber die Labmagenverlagerung des Rindes. Dtsch. Tieraerztl. Wochenschr. 64, 2-7.

[21] Smith, H. A., and Jones, T. C. (1966). Disease of metabolism. In Veterinary Pathology, Smith, H. A., editor, 3rd ed., Lea \& Febiger, Philadelphia, 762-791.

[22] Stevens, C. E., Sellers, A. F., and Supurrell, F. A (1960). Function of the bovine amasum in ingesta transfer. Am. J. Physiol. 198, 449-455.

[23] Titchen, D. A. (1962). Nervous control of motility of the forestomach of ruminants. In Handbook of Physiology, Code, C. F., editor, American Physiological Society, Washington, D.C., 2705-2725.

[24] Yamada, H.. Satoh, M., Miyahara, K., and Hirose, T. (1980). Fluoroscopic findings of the bovine digestive tract by an X-ray television fluoroscopic apparatus for large animals. $J$. Jpn. Vet. Med. Assoc. 33, 164-170 (in Japanese). 
要 約

ウシの第 4 胃変位およびアトニーの発生要因に関する臨林ならびに病理学的研究Ｉ．第 4 胃变位自 然例: 山田明夫（帯広畜産大学獣医学科家畜外科学教室）—ウシの第 4 胃変位掞よびアトニーの発生 要因を明らかにする目的で，第 4 胃変位罹患牛 24 例に対してX 線透視抢よび病理組織学的所見を主体 とした検索を行った。このうち 14 例は第 4 胃整復手術によって治漓したもので，他の 10 例法と殺し， 病理学的に検索した．X 線透視所見では，第 4 胃の变位・拡張の他に，第 I 胃の食滞あるいは鼓脹像, 第 2 胃の収縮力の減退を伴ったアトニーなどの前胃運動機能低下像が全例で観察された．また，第 2 胃 内鋭性金属異物の存在が 22 例 (92\%) で認められた。このうち8 例は，異物が胃壁に刺入して扣り，2 例では，異物が第 2 胃胃壁に強く接触することによって，第 2 胃および第 1 胃運動が明らかに抑制され るのが観察された，病理組織学的所見では，複胃の筋層平滑笳掞よび壁内走行神経束病変が，動脈性細 血管の水腫性を伴い，第 3 胃掞よび第 4 胃で比較的新鮮な病変，第 2 胃で陳旧に傾いた病变として頻繁 に観察された．しかし，噴門直下に異物にもとづく炎症事象が認められた症例では，陳旧に傾いた病変 が，腹部腹側迷走神経幹の複胃での分布領域（第 1 胃を除く複胃）に一致して観察された，以上の成績 から，第 4 胃変位およびアトニ一発現の前状態として，前胃運動機能低下の存在が指摘され，前胃運動 機能低下の誘発要因の一つとして，第 2 胃内鋭性金属異物の胃壁への機械的刺激が重視された。

\section{Explanation of Figures}

Figs. 1-6 are fluoroscopic photographs taken from a $16 \mathrm{~mm}$ film of video tape recordings.

Fig. 1. Case No. 19. Left-sided displacement of the abomasum. Notice the dark, thick, but less distinct abomasal wall (solid arrow) projected on the screen. The blank arrow shows the ruminal wall.

Fig. 2. Case No. 18. Right-sided displacement of the abomasum. Notice the thin but very distinct abomasal wall (solid arrow) projected on the screen.

Fig. 3. Case No. 13. Reticular atony. Notice the bottom of the reticular fundus with sand grains (solid arrow) posterior to the xiphoid cartilage.

Fig. 4. Case No. 18. Ruminal impaction. Notice the level of the ruminal ingesta (solid arrow) immediately below the thoracic vertebrae (blank arrow).

Fig. 5. Case No. 19. Sharp metallic foreign body in the reticulum. Notice implanted wire on the anterior reticular wall (arrow).

Fig. 6. Case No. 21. Geosediments on the abomasal fundus (arrow).

Fig. 7. Case No. 16. Gross lesions of the honeycomb mucosa of the reticulum with holes in- flicted by sharp foreign bodies (arrow).

Fig. 8. Case No. 15. Intramural abscess and fibrous formation in the serosa of the reticulum near the area of the reticular plexus just below the cardia.

Fig. 9. Case No. 23. Ulceration of the omasal groove (arrow).

Fig. 10. Case No. 20. Ulceration of the abomasum (arrow).

Fig. 11. Case No. 15. Relatively fresh lesions in the smooth muscle of the reticulum. Hematoxylin-Eosin stain (H-E). $\times 530$.

Fig. 12. Case No. 16. Relatively fresh lesions in the smooth muscle of the abomasum. H-E. $\times 335$.

Fig. 13. Case No. 15. Rather old lesions in the smooth muscle of the reticulum. H-E. $\times 335$.

Fig. 14. Case No. 19. Relatively fresh lesions in the intramural nerve fibers of the reticulum. H-E. $\times 83$.

Fig. 15. Case No. 15. Rather old lesions in the intramural nerve fibers of the reticulum. H-E. $\times 135$.

Fig. 16. Case No. 18. Chronic abomasal ulcer. H.E. $\times 135$. 

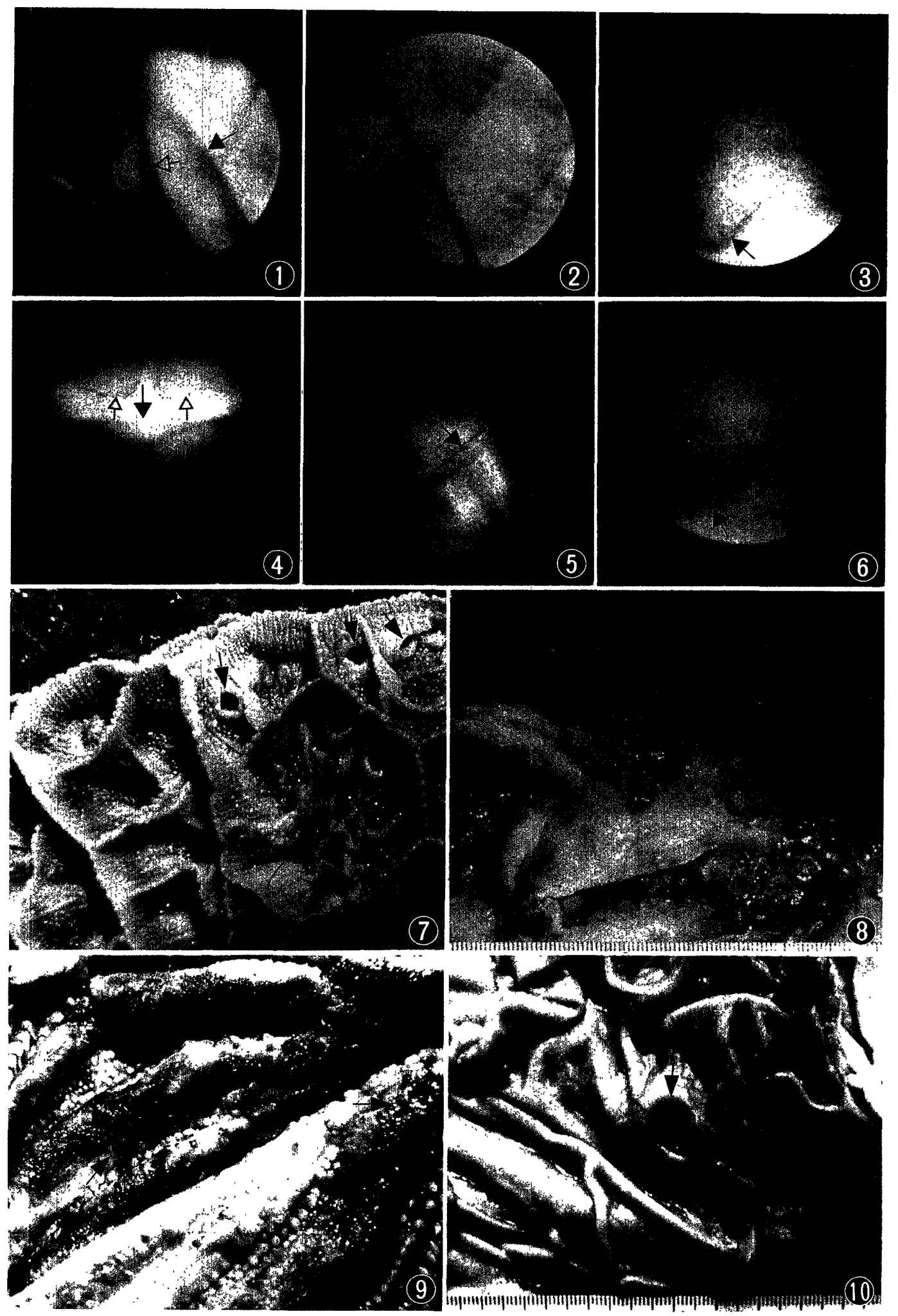


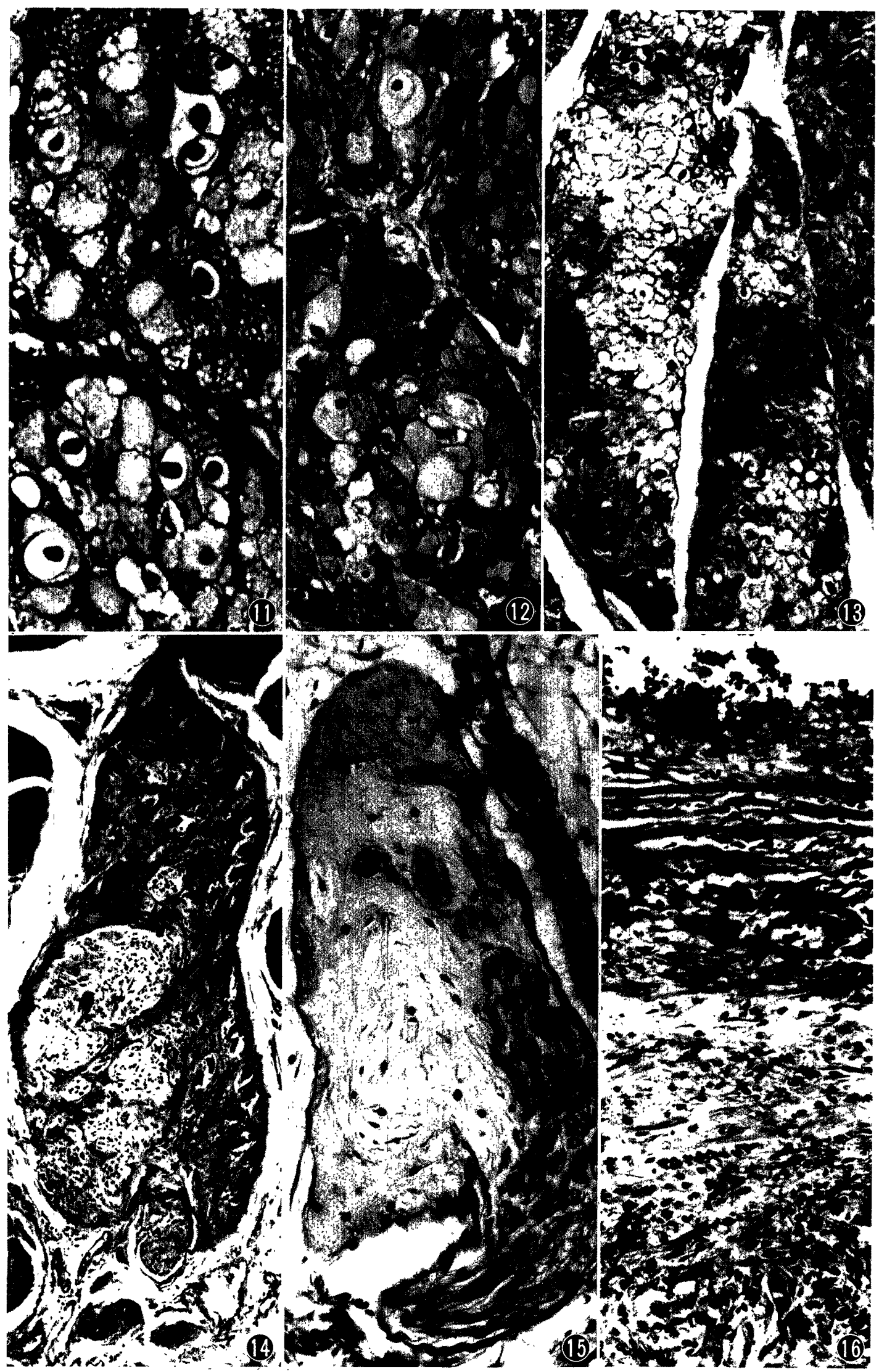

